\title{
Evolution of multifunctional land use systems in mountain areas in Italy
}

\author{
Raffaello Giannini, ${ }^{1}$ Antonio Gabbrielli ${ }^{2}$ \\ 'Dipartimento di Economia, Ingegneria, Scienze e Tecnologie Agrarie e Forestali, Università di \\ Firenze; ${ }^{2}$ Accademia Italiana di Scienze Forestali, Firenze, Italy
}

\begin{abstract}
This work presents an analysis of the evolution of human activity in Italian mountain areas, as regards to agricultural and forestry land use. Due to the large area occupied by woodlands, the analysis focusses on the relationships between man and forests. Three closely linked systems have been analysed: agriculture, pasturage and silviculture, which are primary resources used to satisfy human food and energy requirements. From the point of view of the landscape, crops and forest products remain separate entities, even if a link to pasturage remains. Two typical cases of multifunctional systems have been described. The first is related to the alpine area, and the second one concerns the Apennines. The documentation on land use in mountain areas underlines the deep-seated relationships that have developed over time between human activity and the forest. Until the middle of the $20^{\text {th }}$ century, the agriculture-forestry systems were integrated into field, pasture and woodlands in which the portion dedicated to pasture was dominant. Today, forests play a primary role since they offer economic advantages and when correctly managed they can provide a diversified flow of services.
\end{abstract}

\section{Introduction}

The evolution of multifunctional land use systems in Italian mountain environments is a subject of great interest, not only as far as the description of the land itself is concerned, but also in terms of the rela-

Correspondence: Raffaello Giannini, Dipartimento di Economia, Ingegneria, Scienze e Tecnologie Agrarie e Forestali, Università di Firenze, via S. Bonaventura 13, 50145 Firenze, Italy.

E-mail: raffaello.giannini@unifi.it

Key words: land use, mountain areas, field-pasturage-woodland systems.

Conference presentation: IX AISSA Congress, Firenze 2011.

Received for publication: 23 December 2012.

Revision received: 8 March 2013.

Accepted for publication: 13 Mrch 2013.

CCopyright R. Giannini and A. Gabbrielli, 2013

Licensee PAGEPress, Italy

Italian Journal of Agronomy 2013; 8:e16

doi:10.4081/ija.2013.e16

This article is distributed under the terms of the Creative Commons Attribution Noncommercial License (by-nc 3.0) which permits any noncommercial use, distribution, and reproduction in any medium, provided the original author(s) and source are credited. tionships developed over the centuries between man and the forest.

Some considerations regarding the interaction between the agriculture and silviculture systems are due. First of all, we need to examine the development of land use models and the use of primary resources.

The process of agricultural development began when Man started to understand the importance of a sensible use of: i) propagules (seeds), i.e. the shift from the use only of the single harvest to the combined use of production and harvest; ii) selected propagules (effects of domestication and selection); iii) cultivation techniques aimed to reduce (or eliminate) the obstacles to the potential productivity of the propagules employed. This process began in Italy over 5000 years ago and has not changed greatly over time. It is a process that is still ongoing (although a diversified approach has now been adopted) in the most favourable agricultural areas. However, these areas are not usually found in the mountain regions.

Historically, along with a primary interest in agricultural production, there was a parallel development in the production of animal proteins through husbandry and pasturage. The oldest relationship between man and forest (V millennium BC) was based on grazing as soon as animals were starting to be domesticated. The first livestock were sheep, goats and swine. In the beginning, the woodlands were free for everybody to use and anyone could collect fallen deadwood and graze their animals. Once people started living in communities, the land was taken into possession and the forests were used for logging. Pasturage quickly became a point of conflict, affecting the relationship between the shepherd and the farmer as the farmer's activities impinged on ever larger areas of land previously used for pasture.

The link between the three systems, agriculture, pasturage and silviculture, began to develop as a consequence of the fact that, over time, grazing activities became more closely tied to agriculture. Silviculture, on the other hand, followed a separate evolution. It developed mostly as a response to economic factors because the forests offered an essential extra income for farmers in mountain areas where there were limited opportunities for agriculture. From the point of view of territory and landscape, the multifunctional approach to land use linked the three systems into a single unit in which agriculture and pasture were dependent on human labour. Man had only one concern: to acquire food and energy in the easiest and most convenient way. It is difficult to identify an early, rational, widespread approach to forest management. The forestry systems were (and are still today) focussed on the fall of the natural woody biomass. The spread of agricultural systems started to eliminate the forests, both in flat land areas and along the rivers in the mountains.

These systems have continued to spread up till the present day and the greatest point of conflict has been in mountain areas where the environmental conditions, e.g. steep slopes, have discouraged the spread of agricultural activities. Some agricultural techniques, such as terracing, have allowed the cultivation of grapevines in the Valtellina Valley (Lombardy) and the cultivation of spelt in the upper Garfagnana Valley (Tuscany). Other similar examples could be mentioned while the compartmentalisation of land dedicated to crop cultivation supports a poor agriculture-silviculture integration. 


\section{Land use in mountain areas}

In Italy there are two types of mountain systems: the Alps and the Apennines. While these systems differ from one another for historic and economic reasons, the biggest difference between them is related to ecology.

The alpine area represents approximately one-quarter of the total Italian land surface $\left(75,000 \mathrm{~km}^{2}\right)$, while the Apennine region accounts for approximately two-fifths $\left(120,000 \mathrm{~km}^{2}\right)$. Together they make up approximately $35 \%$ of the total area of the country.

In both zones, two dominant land-use systems linked to the forests were present. The first was found in alpine regions and has been described as pasture with trees where, according to Francesco Piccioli (1908), the woody plants were maintained, either isolated or in groups, along with the pasture areas in a relatively irregular fashion, but with no reduction in the herbaceous plant production. In the Apennines, the second system has been described as understory range, where an appropriate number of animals can graze without damaging the trees or where a certain amount of pasturage is tolerated. The difference between the two environments should also be considered from the point of view of land-economic structure and business, besides the common element shared by both mountain populations regarding the importance of daily work in satisfying the needs of their families. Work was not just a means of acquiring goods to trade for necessities, but it was also important in order to take care of the land, in terms of the place where they lived. These values have changed drastically in the last 70-80 years. Today, mountain areas can provide excellent services, but they have, in part, shifted away from the multifunctionality of agriculture-silviculture-pasturage systems.

An analysis of some cases can be helpful. In the Alps, the social-economic land structure has remained the same over time: the land is either public or private, represented by the Comunità Montana (i.e. the local governing authority), by the Lay Rule (Comunità, Regola) and by the individual farms of varying sizes. The territory is dominated by forests, meadows that can be mowed, pastures above the tree line, and crops located near the urban areas, while the Malga (pastures and a shepherd's hut with cows) is usually shared by the Comunità Montana. The Maso Chiuso (located in Bolzano Province), another typical farm, is managed privately. This is an indivisible farm unit made up of an average $8 \%$ meadow-pasture and $79 \%$ woodlands. The farmers often allow their animals to graze in the forest even if this could lead to disagreements over woodland preservation. Agriculture remains dissociated even if it can provide feed (rye, beans and potatoes, where possible). Livestock breeding remains in the valley from late summer to late spring, when the cows are transferred to the higher pasture and divided into the collective public farms, the Malga, according to the local rules and regulations. Usually the local cowshed was (and still is) integrated with that transferred from flat areas.

The concept of multifunctionality is mostly connected to the forest ecosystem. It combines its potential pabulum with the natural pastures and the production of meadow grass that is set aside for hay (to cut, cure and store) for winter animal feed. Indeed, the intensive pasturage caused such a massive reduction in forests as to lower the upper limit of woodlands by up to $150-200 \mathrm{~m}$.

The land-use model showing the best integration between wood and herbaceous production is that of the pasture with larch which has been widespread also at low elevations and where solar radiations are high. The larch is a plurizone, relatively frugal, deciduous conifer tree, with an open canopy that allows penetration of solar rays. It is a wise choice which offers the best compromise from forests and pasture. This model pre-dates those employed today in agriforestry contexts.

The relationship between forests and pasture became difficult when it was clear that their very survival could be endangered, to the detriment of the entire community. Rules were needed to preserve the multifunctionality of the forest. The community intervention on the part of the Comunità Montana (initially the medieval Comune) mainly addressed the hydrological function of the forest, and also considered preventing and dealing with the damage that can be caused by winds and avalanches, as well as preservation of the environment for collecting wood and harvesting forest fruits.

The developing legislation recognised the strategic importance of the forests and specific laws were created to protect them.

Over the last thirty years, there have been enormous changes with regards to the management of the alpine areas. The socio-economic changes closely related to the new life model have resulted in several particular activities of the agriculture-silviculture-pasturage systems. The biggest changes can be seen in the reduction in grass production and in the amount of land dedicated to pasture associated with the natural increase in woodland. So also the landscape has been changing: the Malga have been turned into opportunities for agritourism; hotels offer Bed and Breakfast, and much pasturage has now been converted into ski slopes.

In the Apennines, a typical example of a multifunctional system is the cultivation of chestnut orchards. The diffusion of this tree has been the biggest influence of man on land-use management and its fruit has provided essential food for many generations over vast inland and mountain areas. The chestnut orchard is similar to an agriforestry multifunctional model: as part of an agricultural entity it provides food (fresh fruit for direct consumption and/or transformation into flour for human and animal consumption), various wood products (firewood or wood for charcoal, industrial tannin, agricultural tools, building, etc.) and pasturage, especially for sheep. Among the so-called secondary products it is worth mentioning mushrooms. For the poorest local populations, the mushrooms represented a miracle from the heavens, because their collection, harvesting and subsequent sale, offered immediate earnings. Thus, chestnut orchards provided added benefit for the farms, often determining the value of the farm itself according to the size, efficiency and productivity of the orchard. Lodovico Piccioli (1922) wrote in his book, Monografia del Castagno, that the model of the chestnut orchard is the best cropping system to respond to the needs, modest as they may be, of closed economies in an environment having difficult communication links, poor soil fertility and a dense population.

Chestnut woodlands are present in all Italian regions. In some regions, even today, they are a dominant part of the mountain landscape, as well as of its history and traditions. At the beginning of the $20^{\text {th }}$ century, in the Apennines, orchards covered 270,000 ha (Piccioli, 1922).

The spread of chestnut cultivation began in Roman times. The chestnut orchards and coppice practices were revitalised towards the end of the Middle Ages, in part due to measures of conservation and diffusion taken by the monastic orders. The Metato, a special shed in the orchards used to dry nuts, was first reported in the early $13^{\text {th }}$ century. Until the first decades of the $19^{\text {th }}$ century, there was no appreciable change in the surface areas occupied by chestnuts, i.e. 800,000 ha.

Chestnut orchards were well cultivated, as indicated by Del Noce (1849), and later by Siemoni (1870), Piccioli (1902, 1922), Pollacco (1938), Bellucci (1953), Carullo (1955) and Giorgi (1960).

Subsequently, the growth of the human population and the spread of more profitable agricultural methods, meant more land was required for grazing and forage cultivation, also in the mountain areas. This led to a general deforestation to acquire new lands for crop. Chestnut orchards were also cut due to the interest in the wood for industrial purposes. Furthermore, social causes, closely linked to the agricultural economics, together with the spread of epidemic diseases, led to a progressive reduction in the chestnut orchards. 
One example serves to illustrate this. During the $16^{\text {th }}$ century, in the Signoria Medicea in Tuscany (excluding the lands belonging to the Duchy of Lucca and Massa) the chestnut orchards covered an area of almost 350,000 ha. In Tuscany today, the area is now estimated to be approximately 75,000 ha of which only 21,000 are cultivated (Bellini, 2009)!

In 2000, in Italy, fruit-bearing chestnut orchards occupied approximately 200,000 ha (Adua, 2000, 2006) (Figure 1) (Del Noce, 1849; Piccioli, 1922; Giorgi, 1960; Fenaroli, 1945; Adua, 2000, 2006).

The consequential reduction in nut production has continued up to the present day, even if the decline has slowed down in the last decade of the last century. It is now common for small owner-producers to continue to cultivate the orchards. In mountain areas, the inherited land divisions are divided into cadastral units of land each destined for different crops. Farms tend to be smaller and consequently the chestnut woodlands can be managed appropriately.

In the period before World War II, again in the Tuscan Apennines, most farms were small, individually owned of an average size of 12 ha. These were divided up into $20 \%$ for cropland, $47 \%$ for chestnut orchards, and $33 \%$ for pasturage and other woodlands. Chestnut orchards dominated this agriculture-silviculture-pasturage combination and November was busiest working period. This was when the nuts were harvested, transported and dried.

Over the past twenty years, several meetings, seminars, national and international conferences have focussed on the chestnut, and this is indicative of the continued interest about the conservation and cultivation of this species, even if, since the 1980s, greater attention has been directed toward the production of highly qualified fruits (Alvisi and Gajo, 1985). Compared with its role in the past, the chestnut orchard ecosystem has grown in importance. The social role of the ecosystem should also be mentioned because of the emotions it evokes and the way in which it keeps local traditions alive. Environmental and landscape factors are equally important, as well as those linked to the preservation of biodiversity. Finally, there is new interest in the transformation of the chestnut fruits, helping to heighten its profile as a typical product and creating short production chains. Preservation of the chestnut orchard is also very important because of the national historic-botanic patrimony it has represented over the past 700-800 years.

\section{Proposals for the future}

In the past, the multifunctionality of agro-forestry mountain systems was led by pasturage and animal husbandry. Today, in the Alps and in the Apennines, the forest plays the primary role. The changes that have taken place in land use over the last eighty years show an increase in the area covered by forests and a decrease in areas allocated to the production of forage (Table 1). In favourable conditions, for example in abandoned pastures, the woodlands have expanded naturally and this helps conserve the environment. From a general point of view, the woodlands represent, perhaps more than any other ecosystem, an advantageous resource that, if correctly managed, can provide a diversified flow of services. First of all, its role in terms of preservation of the biodiversity and genetic variability must not be underestimated. Forest soil is like a precious jewel box: only a part of its hidden treasures (i.e. plant and animal germplasm) can be seen. Forest ecosystems have always been a primary element in setting up protected areas and parks. At the same time, today these ecosystems are a fundamental economic tool and resource for territorial integration in mountain communities for animal husbandry, grazing, wildlife and tourism. From a functional perspective, the forest is a complex environment. This rich diversity still protects the territory, regulates the water resources, mitigates the effects of climate change through an accumulation of carbon, and reduces $\mathrm{CO}_{2}$ (Luyssaert et al., 2008; Schmidt et al., 2011).

Modern life-style and aspirations have led to considerable changes in the mountain areas. Tourism represents a highly valuable new element for agriculture-sylviculture-pasturage systems. During the first decades of the last century, tourism brought valuable wealth to entire valleys. The alpine areas, which in the past only attracted the rich élite, were the first to feel the effect. The phenomenon was later extended to the Apennines, where it continues today across the whole social spectrum. Tourism has sprung up in those areas where the landscape, composed of alternating agriculture forest systems and a scenic backdrop of cliffs and rocky peaks, is highly suggestive and seems to offer itself as the ideal location for a variety of outdoor activities. The locals greet the new arrivals with enthusiasm, and encourage this new reality without perhaps being fully aware of the possible impact on a territorial level. The growth of urbanisation and the introduction of tourist infrastructure, ski lifts, ski runs and artificial snow, have all radically changed the landscape, often with little respect for eco-sustainability and preservation of these natural ecosystems. They certainly favour economic development but the daily commitment to the production of primary products drastically changes. However, great attention is still given to the forest as a renewable source of wood. The wood production chain maintains its economic-financial importance because it is linked to industrial transformation and can be integrated with tourism.

There are various future perspectives for chestnut woodlands. For example, the massive and fast diffusion of the new pest, Dryocosmus spp., has raised further uncertainties. But there is still great interest in the production of the valuable chestnut fruits and this encourages orchard conservation and cultivation. The Italian Ministry of Agriculture is promoting the recovery and the development of this sector. In the past, many chestnut orchards had been converted into

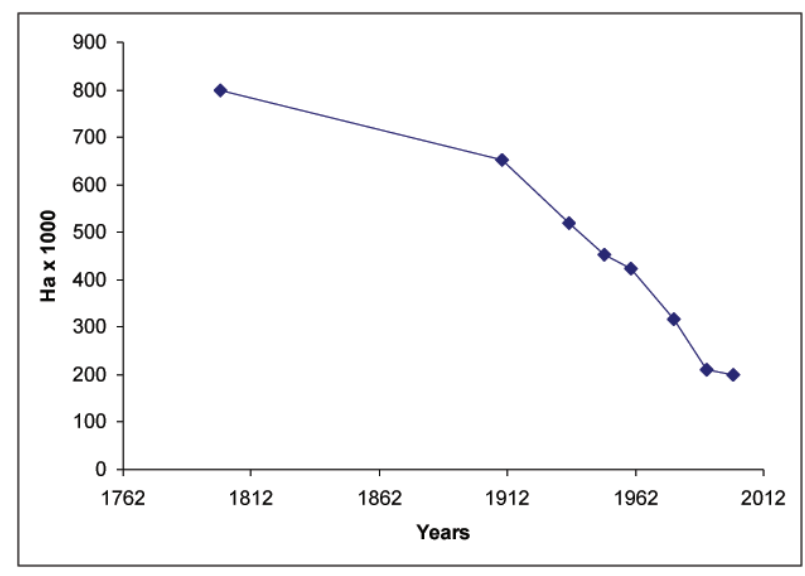

Figure 1. Variation of surface of the chestnut orchards in Italy.

Table 1. Variation of land use during the period 1922-2007.

\begin{tabular}{lc} 
& $\%$ \\
Crops & -47.7 \\
Orchard & 56 \\
\hline Permanent forage crops & -49 \\
Forage crops & -29 \\
\hline Forest land & 51.2 \\
\hline
\end{tabular}


coppices and also today this represents a good silvicultural solution. The value of wood production can be exploited with appropriate operating techniques. The results of many studies also show that better management of abandoned chestnut orchards is promoting the natural dynamics toward mixed stands. These strategies are supported by the reappearance of past pest and disease attacks and the threat posed by new ones.

In general, the forest ecosystems can be preserved through management methods aimed at their correct use and favouring their functional efficiency (Giannini and Susmel, 2006). The teachings of Gayer, first presented in 1880 and later continued through the Schools of Forestry in Switzerland, France and Italy, have been a reference point for silviculture doctrine and can be summed up by the expression close to nature, or in other words, a silviculture (or a forest use) based on an ecological perspective (de Philippis, 1972; Susmel, 1991). However, it is important to pay attention to the increasingly widespread belief that forests have an unlimited capacity to provide services, without considering the strong dualism among their diversified uses (Giannini, 2011). The relationships between wild live, $C$ storage, economic goals (wood and other products) and social functions (tourism, landscape) are currently of topical interest.

We are living a moment of great difficulty on a global scale, and this could provoke strong emotional responses. For example, wood production has once more gained interest as a way to resolve the energy crisis. Also in this case, carefully reasoned management choices are necessary. The cultivation of poplars for the production of wood biomass outside the forest could be a solution. Greater efforts are required to respond to energy needs even if there are real difficulties in creating the plantations given the shortage of food, land and labour. For these reasons, it is essential to preserve full woodland bio-ecological functionality, especially for the well being of future generations.

\section{References}

Adua M, 2000. Il castagno: un albero da riscoprire. Ed. Adramo, Catanzaro, Italy.

Adua M, 2006. La filiera "castagno da frutto" in Italia: storia, attualità, problematiche e prospettive. pp 112-117 in Atti del $\mathrm{IV}^{\circ}$ Convegno Nazionale, Montella (AV), Italy.

Alvisi F, Gajo P, 1985. Problemi economico-commerciali del castagno. pp 23-65 in Atti del II Convegno Interegionale del castagno, Castel del
Rio (B0), Italy.

Bellini E, Giordani E, Marinelli C (eds.), 2009. Marrone del Mugello IGP: tradizione e qualità. 3rd ed. Camera di Commercio di Firenze, Firenze, Italy.

Bellucci V, 1953. L'economia forestale della Toscana. Ann. Acc. Ital. Sci. For 1:273-464.

Carullo F, 1955. Boschi di Castagno: loro conservazione e loro miglioramento. Atti Congresso Nazionale di Selvicoltura. Ann. Acc. Ital. Sci. For. 1:159-96.

de Philippis A, 1972. Ecologia e selvicoltura: antitesi 0 armonia? L'Italia Forestale e Montana 27:140-51.

Del Noce G, 1849. Trattato istorico, scientifico ed economico delle Macchie e delle Foreste del Granducato di Toscana. Ducci Ed., Firenze, Italy.

Fenaroli L, 1945. Il Castagno. R.E.D.A., Roma, Italy.

Giannini R, 2011. Utilità e servizi delle foreste: demagogia 0 tecnica dello struzzo? L'Italia Forestale e Montana 66:463-7.

Giannini R, Susmel L, 2006. Foreste, boschi, arboricoltura da legno. Forest@ 3:464-87.

Giorgi E, 1960. Il castagneto da frutto in Toscana. Osservatorio Nazionale di Economia Montana e Forestale, Firenze. Coppini \& C., Firenze, Italy.

Luyssaert S, Detlef Schulze E, Borner A, Knohl A, Hessenmoller D, Law BE, Ciais P, Grace J, 2008. Old-Growth Forests as global carbon sinks. Nature. 455:213-5.

Piccioli L, 1902. Monografia del Castagno. 1st Ed. Tip Landi, Firenze, Italy.

Piccioli F, 1908. Boschi e pascoli. U.T.E.T., Torino, Italy.

Piccioli L, 1922. Monografia del Castagno. 2nd Ed. Tip. Spinelli, Firenze, Italy.

Polacco F, 1938. Indagine sulla coltivazione del castagno da frutto in Italia. Bollettino mensile di statistica agraria e forestale. Istituto Nazionale di Statistica (ISTAT), Roma, Italy.

Schmidt A, Hanson C, Kathilankal J, Law BE, 2011. Classification and assessment of turbulent fluxes above ecosystems in North-America with self-organizing feature map networks. Agr. Forest Meteorol. 151:508-20.

Siemoni GC, 1870. Del castagno, sua storia, sua coltivazione, sue varietà. Risorgimento Agricolo 1:2-3.

Susmel L, 1991. Evoluzione della selvicoltura in alcune aree del Veneto. pp 15-28 in Atti giornata preparatoria, Asiago 1991, II Congresso Nazionale di Selvicoltura, Venezia, Italy. 